\title{
頸㩆砂時計腫手術例の検討
}

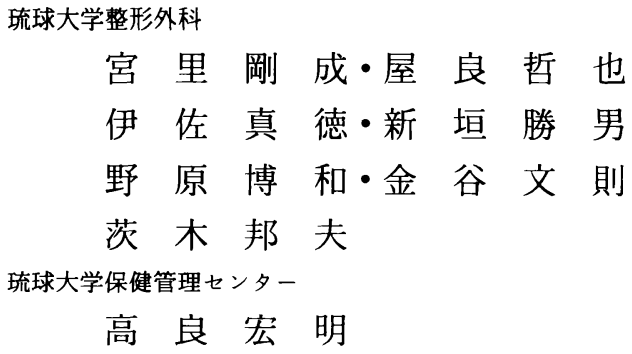

\section{Surgical Treatment for Cervical Dumbbell Tumor}

\author{
Takenari Miyazato, Tetsuya Yara, Shintoku Isa, Katsuo Arakaki, \\ Hirokazu Nohara, Fuminori Kanaya, and Kunio Ibaraki \\ Department of Orthopedic Surgery, School of Medicine, University of the Ryukyus \\ Hiroaki Takara \\ Health Administration Center, University of the Ryukyus
}

We reviewed 14 patients with cervical dumbbell tumor who underwent surgical treatment They consisted of 7 males and 7 females, and the mean age at surgery was 44.4 years old. They revealed 12 schwannomas and 2 meningiomas.

In 8 patients, the dumbbell tumor was extirpated. In 5 out of the remaining 6 patients, the intra-spinal lesion of the tumor was removed, but anterior extra-spinal lesion, which could not be removed by posterior approach, was left alone. In only 1 patient, the intraspinal lesion located in front of the spinal cord was left alone. Neurological symptoms improved in 12 out of 14 patients, and clinical recovery rate averaged $57.8 \%$. None showed neurological deficit, but 3 cases developed meningitis after surgery.

In the 8 cases with complete extirpation of the tumor, none showed recurrence. However in 3 out of 6 cases, enlargement of the remaining tumor was evidently observed.

In cases of dumbbell tumors where the intra-spinal portion extends to the anterior paravertebral area, both the anterior and posterior approaches should be performed to extirpate the dumbbell tumor.

Key words : Cervical dumbbell tumor (頸䯣砂時計腫), Anterior approach (前方進入法), Posterior approach（後方進入法）, Meningitis（髄膜炎）

\section{はじめに}

頸䯣砂時計腫は，脊䯣横断面にお打る腫瘍の局在に よっては，後方アプローチ単独での摘出が困難で，前
方アプローチの追加が必要な例む少なくない，今回我々

は, 頸髄砂時計腫手術例の臨床成績, 合併症を調查す るとともに，腫瘍の遺残および再発の有無をMRI に て観察し, 腫瘍の局在により選択すべき手術法を検討 
したので報告する。

\section{対象及び方法}

症例は, 1989 年から 1998 年までに当科において手 術を施行した頸䯣腫瘍 23 例中砂時計型腫瘍を呈した 14 例であった。性別は男 7 例, 女 7 例で, 手術時年 令は 21 歳から 65 歳, 平均 44.4 歳であり, 経過観察 期間は 5 力月から 10 年 3 力月, 平均 4 年 2 力月であっ た. 奉䯣横断面における腫痬の形態は戸山分類で, Type IIb が 4 例, Type IIIb が6例, Type I , Type II a, Type IIIa, Type VI が各々 1 例ずっであった. 腫瘍の 病理診断は, Schwannoma が 12 例, Meningioma が 2 例であった. 術式は後方アプローチ 10 例, 前方ア プローチ 3 例, 前方および後方アプローチの併用が 1 例であった．臨床成績として頝䯣症は日整会䅡椎症性 脊誦症治療成績判定基準（JOA スコア）を用いて評 価し，また合併症を調查した。画像評価は MRI 横断 像を用いて腫瘍の遺残および再発の有無を調べ，術式 との関連性を検討した，遺残腫瘍の増大率は腫瘍面積 之隣接椎体面積の比の増大率を NIH Image を用いて 計測した。

\section{結}

果

JOA スコアを 17 点満点の 1 例を除く 13 例で検討 した. 術前平均 12.1 点が術後平均 15.3 点となり, 平 林法による平均改善率は $57.8 \%$ であった。術前後とも 14 点の 1 例を除く全例で改善していた（図 1 ).
合併症では䯣膜炎が 14 例中 3 例にみられた。䯣膜 炎の診断は発熱，頭痛の症状に加えて檤液検査による 多核白血球数 780 から 20000 の増加を根拠とした。治 療は抗生剂の静注と髄注の併用を 2 例に，静注単独を 1 例に行い 3 例とも治癒した。

腫瘍の遺残は合計 6 例でみられた。 戸山分類による うちわけは Type II b で後方法を施行した 2 例中 1 例, 前方法の 2 例中 1 例であり, さらに Type IIIb では後 方法の 5 例中 4 例であった（表 1 ）.

腫瘍が増大したのは 4 例で縮小したのは 2 例であっ た. Type III b の 3 例は $20 \%$ 以上の明らかな増大がみ られ，Type II bの 1 例は 59\%の縮小がみられた（図 2 ).

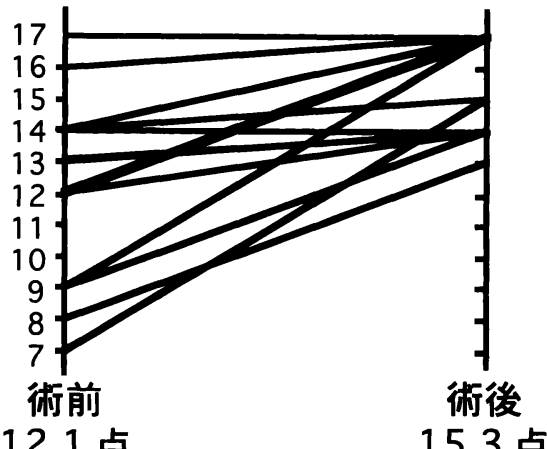

平均 12.1 点 15.3 点 （平均改善率 $57.8 \%$ )

図 1 術前後の JOA スコアと平均改善率

表 1 遺残腫瘍に対する手術方法

\begin{tabular}{|c|c|c|c|c|c|c|c|}
\hline 症例 & 年令 & 性別 & 腫瘍高位 & 戸山分類 & アプローチ & 固定の有無 & 遺残腫瘍 \\
\hline 1 & 58 & 男 & $\mathrm{C} 3 / 4$ & I & 後方 & 有 & 無 \\
\hline 2 & 46 & 女 & $\mathrm{C} 1 / 2$ & II a & 後方 & 無 & 無 \\
\hline 3 & 44 & 女 & $\mathrm{C} 4 / 5$ & II b & 前方 & 有 & 無 \\
\hline 4 & 49 & 女 & $\mathrm{C} 2 / 3$ & II b & 後方 & 有 & 有 \\
\hline 5 & 39 & 男 & $\mathrm{C} 7 / \mathrm{T} 1$ & $\Pi \mathrm{b}$ & 前方 & 無 & 有 \\
\hline 6 & 21 & 男 & $\mathrm{C} 1 / 2$ & II $\mathrm{b}$ & 後方 & 無 & 無 \\
\hline 7 & 55 & 男 & $\mathrm{C} 6 / 7$ & III a & 後方 & 有 & 無 \\
\hline 8 & 27 & 女 & $\mathrm{C} 2 / 3$ & III b & 後方 & 有 & 有 \\
\hline 9 & 57 & 女 & $\mathrm{C} 4 / 5$ & III $b$ & 後方 & 有 & 有 \\
\hline 10 & 54 & 男 & $\mathrm{C} 4 / 5$ & mII b & 後方 & 有 & 有 \\
\hline 11 & 34 & 女 & $\mathrm{C} 2 / 3$ & III $b$ & 後方 & 無 & 有 \\
\hline 12 & 65 & 男 & $\mathrm{C} 4 / 5$ & III $b$ & 前方 & 有 & 無 \\
\hline 13 & 53 & 男 & $\mathrm{C} 3 / 4$ & III b & 後方 & 有 & 無 \\
\hline 14 & 39 & 女 & $\mathrm{C} 2 / 3$ & VI & 前方 + 後方 & 有 & 無 \\
\hline
\end{tabular}




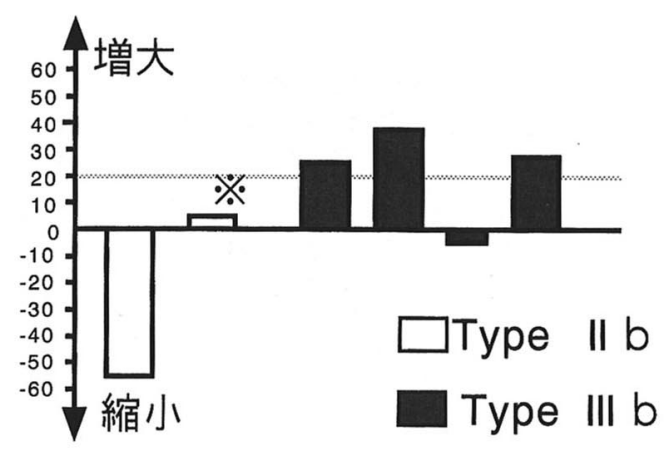

図 2 遺残腫瘍の増大率

* 印の 1 例は前方法施行後脊柱管内に腫瘍が遺残し，他の 5 例は後方法施行後前方に腫瘍が遺残している。

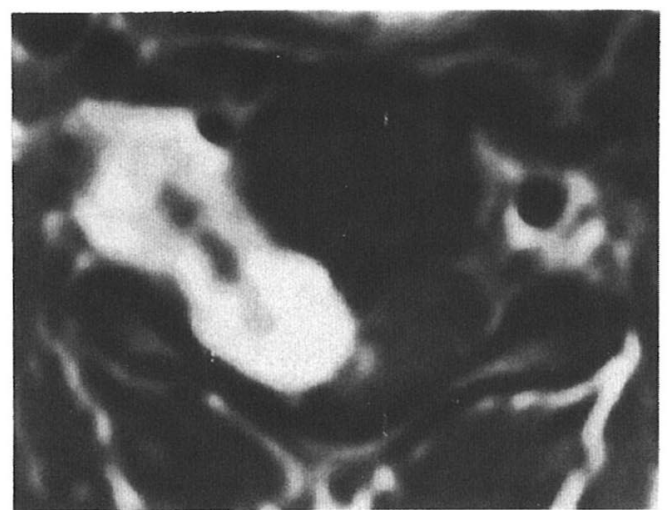

a

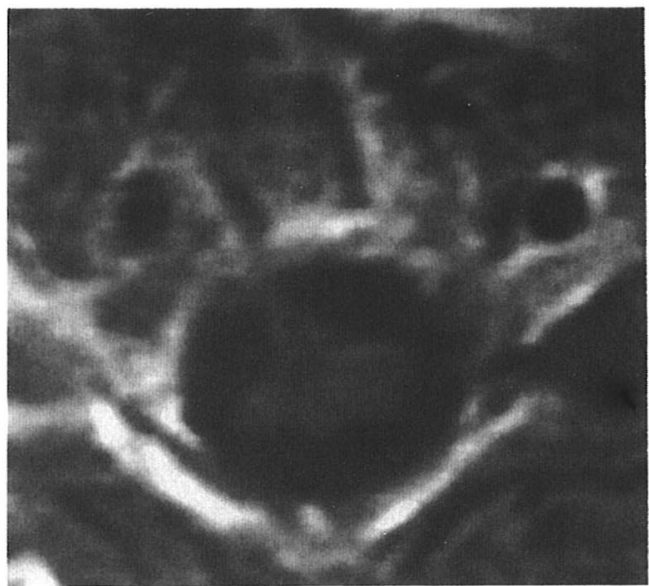

b

図 344 歳, 女性, Type II b の砂時計腫湯に対して前方進入法施行.

a. 術前の enhanced MRI

b. 術後 8 力月の enhanced MRI

腫瘍は完全に消失している.

症例 1

44 歳, 女性. 戸山分類 Type II b $の$ 腫瘍に対し前 方法を施行した．MRIにて術前造影された腫瘍は術 後 8 カ月では完全に消失し, JOA スコアは 14 点から 15 点に改善した（図3）.

\section{症 例 2}

34 歳, 女性. 戸山分類 Type III b の腫瘍に対し後 方法を施行した。 JOA スコアは 9 点から 17 点に改善 した．術前造影された腫瘍は術中, 椎骨動脈からの出
血により全摘出を断念した。腫場は術後 2 年 3 力月で は椎間孔に限局していたが, 術後 10 年では増大率 24 \%となり春柱管内へ進展していた（図 4 ）.

考察

脊䯣砂時計腫の外科的治療に対して岩崎 ${ }^{11}$ は, 完 全摘出が基本であり，まず後方より一期的完全摘出を 試みるが，腫瘍の高位拉よび傍脊椎領域の前方の拡が りによっては前方法の追加が必要であると報告してい る。一方鎌田らや中村ら ${ }^{2)}{ }^{3)}$ は，遺残腫瘍の著明な増 大はまれであり, 脊䯣症状がなければ経過観察も選択 


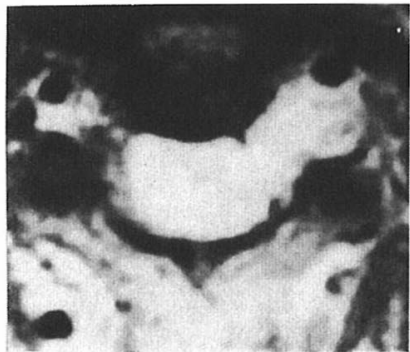

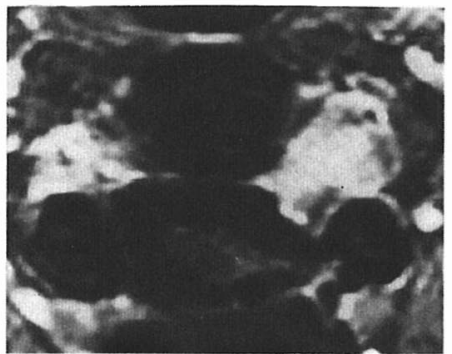

b

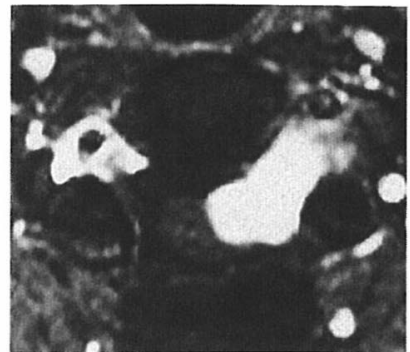

c

図 434 歳, 女性, Type III b の砂時計腫痬に対して後方進入法施行.

a. 術前の enhanced MRI 術中椎骨動脈からの出血により全摘出を断念する.

b. 術後 2 年 3 力月の enhanced MRI 遺残腫場は椎間孔に限局している.

c. 術後 10 年の enhanced MRI

腫瘍は増大率 $24 \%$ となり脊柱管内へ進展している.

肢の 1 つであると報告している. 我々の症例では, 後 方法を施行した Type II b と Type III b の計 5 例で腫 瘍は遺残し，うち 3 例で明らかに増大し腫瘍は脊柱管 内まで進展した，今回の検討にて，腫瘍が前方の傍脊 椎領域におよび後方法にて脊柱管外部分が完全摘出不 能であった例に対しては, 前方法を追加し腫瘍の全摘 出が必要であると考えられた.

䯣膜炎を合併した 3 例については血中白血球数増加 がなくても発熱や頭痛が持続するため䯣液検査を施行 し䯣膜炎の診断を得ることができた，我々は以前，難 治性の䯣膜炎や骾膜炎後の水頭症を経験しており，積 極的に䯣液検査を施行している. 腫瘍摘出術後の䯣膜 炎は特に留意すべき合併症と考えられた。

\section{結語}

2. 頚髄症の改善率は $57.8 \%$ であった。

3. 3 例に䯣膜炎を合併した。

4. 遺残腫瘍は 6 例であり，うち 3 例では明らかに増 大した。

5. 腫瘍が前方におよぶすのは, 後方法に前方法の追 加を考慮すべきと考えられた。

\section{参考文 献}

1）岩崎喜信, 飛騨一利, 阿部弘 : 砂時計形神経鞘腫の手 術手技. 脊椎脊䯣ジャーナル, 10 : 105-108, 1997.

2）鎌田修博ら：脊檤腫瘍非手術例の検討。臨整外， 33 : 433-437, 1998.

3）中村 真ら：脊䯣砂時計腫の脊柱管外遺残腫瘍の術後 MRIによる検討. 整形外科と災害外科, $48: 58-60$, 1999.

1. 頸䯣砂時計腫手術 14 例について検討した。 